\title{
Conservation of molecular and cellular phenotypes of invariant NKT cells between humans and non-human primates
}

\author{
Krystle K. Q. Yu ${ }^{1}$ • Damien B. Wilburn ${ }^{2}$ • Joshua A. Hackney ${ }^{3}$ - Patricia A. Darrah ${ }^{3} \cdot$ Kathryn E. Foulds ${ }^{3}$. \\ Charlotte A. James ${ }^{1,4} \cdot$ Malisa T. Smith ${ }^{1} \cdot$ Lichen Jing $^{1} \cdot$ Robert A. Seder $^{3} \cdot$ Mario Roederer $^{3}$ - David M. Koelle ${ }^{1,5,6,7,8}$. \\ Willie J. Swanson ${ }^{2} \cdot$ Chetan Seshadri $^{1,9}$
}

Received: 28 February 2019 / Revised: 26 April 2019 / Accepted: 30 April 2019 / Published online: 23 May 2019

(C) The Author(s) 2019

\begin{abstract}
Invariant NKT (iNKT) cells in both humans and non-human primates are activated by the glycolipid antigen, $\alpha$ galactosylceramide ( $\alpha$-GalCer). However, the extent to which the molecular mechanisms of antigen recognition and in vivo phenotypes of iNKT cells are conserved among primate species has not been determined. Using an evolutionary genetic approach, we found a lack of diversifying selection in CD1 genes over 45 million years of evolution, which stands in stark contrast to the history of the MHC system for presenting peptide antigens to T cells. The invariant T cell receptor (TCR)- $\alpha$ chain was strictly conserved across all seven primate clades. Invariant NKT cells from rhesus macaques (Macaca mulatta) bind human CD1D- $\alpha$-GalCer tetramer and are activated by $\alpha$-GalCer-loaded human CD1D transfectants. The dominant TCR- $\beta$ chain cloned from a rhesus-derived iNKT cell line is nearly identical to that found in the human iNKT TCR, and transduction of the rhesus iNKT TCR into human Jurkat cells show that it is sufficient for binding human CD1D- $\alpha$-GalCer tetramer. Finally, we used a 20color flow cytometry panel to probe tissue phenotypes of iNKT cells in a cohort of rhesus macaques. We discovered several tissue-resident iNKT populations that have not been previously described in non-human primates but are known in humans, such as TCR- $\gamma \delta$ iNKTs. These data reveal a diversity of iNKT cell phenotypes despite convergent evolution of the genes required for lipid antigen presentation and recognition in humans and non-human primates.
\end{abstract}

Keywords CD1D $\cdot$ iNKT cells $\cdot$ Non-human primate $\cdot$ T cell receptor

\section{Introduction}

T cells are activated by antigens bound to antigen-presenting molecules on the surface of antigen-presenting cells through

Electronic supplementary material The online version of this article (https://doi.org/10.1007/s00251-019-01118-9) contains supplementary material, which is available to authorized users.

Chetan Seshadri

seshadri@u.washington.edu

1 Department of Medicine, University of Washington, Seattle, WA, USA

2 Department of Genome Sciences, University of Washington, Seattle, WA, USA

3 Vaccine Research Center, National Institute of Allergy and Infectious Diseases, National Institutes of Health, Bethesda, MD, USA

4 Department of Pathology, Molecular Medicine and Mechanisms of Disease Program, University of Washington, Seattle, WA, USA interactions with cognate $\mathrm{T}$ cell receptors (TCRs). The most widely studied antigen presenting systems are the major histocompatibility complex (MHC) class I and II genes which facilitate the presentation of peptide antigens to T cells (Garcia
5 Department of Laboratory Medicine, University of Washington, Seattle, WA, USA

6 Department of Global Health, University of Washington, Seattle, WA, USA

7 Benaroya Research Institute, Seattle, WA, USA

8 Vaccine and Infectious Diseases Division, Fred Hutchinson Cancer Research Center, Seattle, WA, USA

9 Tuberculosis Research \& Training Center, University of Washington, Seattle, WA, USA 
et al. 1996). Humans express three MHC class I genes, designated HLA-A, HLA-B, and HLA-C, which are among the most polymorphic in the human genome. It is a selective advantage not only for an individual to express several class I molecules to bind different sets of peptide antigens but for a population to have many alleles segregating among its members (Carrington et al. 1999; Wills and Green 1995). Orthologs of human HLA-A, HLA-B, and HLA-C have only been identified in African apes (chimpanzee, bonobo, gorilla, and orangutan) but not in Old World monkeys (macaques and baboons) (Adams and Parham 2001), all of which are considered simian primates. Other primate species have either homologous loci or deletions and duplications of these genes. Thus, the evolution of MHC class I genes in primates reflects the selective adaptation to the unique immune pressures of each species.

The CD1 family of antigen-presenting molecules is highly similar to MHC class I genes except that it evolved to present lipid rather than peptide antigens to $\mathrm{T}$ cells. Humans express five $\mathrm{CD} 1$ genes (CD1A, CD1B, CD1C, CD1D, and CD1E) that vary in the types of lipids that they bind, as well as their patterns of cellular expression and intracellular trafficking (Kasmar et al. 2009). The five human CD1 genes are tightly clustered on chromosome 1, while the MHC loci are separately located on chromosome 6 . In the chicken genome, two CD1 genes are syntenic with the MHC locus, suggesting that CD1 was present in an ancient version of the MHC locus that arose at least 300 million years ago at the time of the last common ancestor of avians and mammals (Salomonsen et al. 2005). Subsequently, the CD1 and MHC loci separated as a result of recombination to a different chromosome.

CD1 gene families have been identified in nearly every mammalian genome that has been sequenced to date (Reinink and Van Rhijn 2016). The most extensively studied is the murine system which contains only one ortholog of human CD1D (Balk et al. 1991). Both human and mouse CD1D activate a specialized population of $\mathrm{T}$ cells called invariant NKT (iNKT) cells. Murine iNKT cells are able to lyse human CD1Dexpressing target cells pulsed with $\alpha$-galactosylceramide $(\alpha$ GalCer) (Ishihara et al. 2000; Nicol et al. 2000; Nieda et al. 1999). Human CD1D tetramers loaded with $\alpha$-GalCer are able to bind mouse iNKT cells defined by NK1.1 expression (Karadimitris et al. 2001). Crystal structures of human and mouse CD1D have been solved and show that the molecular interactions between CD1D and the iNKT cell TCR are highly similar (Borg et al. 2007). Further, human iNKT cell TCRs bind to mouse CD1D loaded with $\alpha$-GalCer with an affinity that is comparable to the mouse iNKT cell TCR (Kjer-Nielsen et al. 2006). Collectively, these data suggest cross-species conservation of the molecular mechanism of antigen recognition by iNKT cells. However, there are also notable differences between human and mouse iNKT cells. Human iNKT cells express a semi-invariant TCR consisting of a germline rearrangement of TRAV10 and TRAJ18 in the TCR- $\alpha$ chain and a limited diversity of TCR- $\beta$ chains, the most common of which is TRBV25 (Dellabona et al. 1994; Porcelli et al. 1993). The mouse iNKT cell TCR is highly similar but not identical. Of the 25 residues within the TCR- $\alpha$ shown to mediate contact with CD1D or $\alpha$-GalCer, eight are not conserved between mouse and human (Borg et al. 2007). There is even less conservation within the TCR- $\beta$ with different gene segment usage and none of the seven residues showing conservation between species (Borg et al. 2007). These data show that while CD1D and iNKT cells have remained associated through evolution, the molecular mechanisms facilitating their interactions may differ between species.

A number of studies have begun to elucidate the functions of iNKT cells in non-human primates. Murine CD1D tetramers loaded with $\alpha$-GalCer with or without monoclonal antibodies targeting specific epitopes on the invariant TCR- $\alpha$ chain have been used to isolate iNKT cells from rhesus (Macaca mulatta), cynomolgus (Macaca fascicularis), and pig-tailed (Macaca nemestrina) macaques (Fernandez et al. 2012, 2009; Gansuvd et al. 2008; Liu et al. 2006; Motsinger et al. 2003). More recently, human CD1D tetramers loaded with $\alpha$-GalCer were used to study iNKT cells in sooty mangabeys (Cercocebus atys) (Rout et al. 2012, 2010a, b). Experiments conducted with $\alpha$-GalCer pulsed human dendritic cells and human or mouse CD1D-transfected cell lines confirmed CD1D-dependent antigen recognition and activation of iNKT cells in non-human primates (Motsinger et al. 2003; Rout et al. 2010b). Similar to mouse and human iNKT cells, iNKT cells present in the peripheral blood of non-human primates produce large amounts of IFN- $\gamma$ and IL-4 upon stimulation with $\alpha$-GalCer and display an effector memory phenotype characterized by expression of CD45RO, CCR7, and CD28 but not CD62L (Gansuvd et al. 2003; Rout et al. 2010b). Despite these similarities, a number of notable differences have also been observed. In humans, canonical iNKT cells express the TRBV25 gene segment, while in cynomolgus and rhesus macaques, this does not seem to be the case (Gansuvd et al. 2003; Motsinger et al. 2003). Human blood iNKT cells are typically $\mathrm{CD} 4^{+}$or $\mathrm{CD} 4^{-} \mathrm{CD} 8^{-}$and express CD161 while blood iNKT cells in rhesus macaques are usually $\mathrm{CD}^{+}$and lack CD161 (Gansuvd et al. 2003). Finally, there is very little data regarding tissue-specific phenotypes of iNKT cells in non-human primates.

We addressed how CD1 genes and iNKT cells are conserved among humans and non-human primates using evolutionary genetics as well as molecular and cellular immunology approaches. In stark contrast to the MHC system for peptide antigen presentation, we find that the five-gene CD1 locus for lipid antigen presentation has remained intact without significant duplications or deletions over approximately 45 million years of simian evolution. Gene segments encoding the semiinvariant TCR- $\alpha$ were conserved across all primate clades, revealing a remarkable example of convergent evolution 
between genes encoding antigen presentation and recognition. Cloning and reconstitution studies confirmed that the rhesus iNKT cell TCR was sufficient to bind human CD1D tetramer and become activated by human CD1D transfectants. Finally, we used multi-parameter flow cytometry to discover tissuespecific iNKT cell populations in non-human primates that have human analogs. Thus, iNKT cells exist as diverse cellular phenotypes in both humans and non-human primates despite strict conservation of the genes mediating lipid antigen presentation and recognition.

\section{Materials and methods}

\section{Evolutionary genetics}

Primate CD1 homolog sequences were acquired using a combination of existing repositories. For human, chimpanzee, gorilla, orangutan, gibbon, olive baboon, and marmoset, homo$\log$ sequences were downloaded from Ensembl version 89, and only homologs located on chromosome assemblies were included. For green monkey and crab-eating macaque, custom scripts were used to reconstruct likely open reading frames (ORFs) from available reference genomes. Briefly, the human $\mathrm{CD} 1$ homolog sequences were used as BLAST queries to identify putative exons, gene coordinates were identified based on exon contiguity within $20 \mathrm{~kb}$, and likely open reading frames were extracted from these loci using Exonerate version 2.2 with human $C D 1$ sequences as queries. Rhesus macaque $\mathrm{CD} 1 \mathrm{cDNA}$ sequences were retrieved from Genbank (accession \#AB458511-AB458513, NM001033114, AY094979). A CD1 gene tree was constructed from the primate $\mathrm{CD} 1$ sequences, in addition to the two chicken homologs available in Ensembl for rooting, by first aligning sequences using Fast Statistical Alignment (FSA) version 1.15.9, then constructing a maximum likelihood tree using Randomized Axelerated Maximum Likelihood (RaxML) version 8.2.8 with the PROTGAMMAJTT model and bootstrap probabilities calculated from 200 replicates.

Following identification as TRAV10 and TRAJ18 in rhesus macaques, the human sequences for each locus were used as queries in nucleotide BLAST searches to identify likely orthologous regions in additional simian genomes (chimpanzee, gorilla, orangutan, gibbon, rhesus macaque, crab-eating macaque, baboon, green monkey, marmoset). The identified locus with the lowest $e$ value was extracted using the "faidx" command in SAMtools, translated in the correct reading frame, and aligned using FSA.

\section{Animals}

Peripheral blood mononuclear cells (PBMC) from a healthy 3year-old female Chinese rhesus macaque were isolated from whole blood by a standard Ficoll method and cryopreserved in liquid nitrogen. The cells were used to obtain data in Figs. 2 and 3. Samples used for tissue staining in Fig. 4 were from cryopreserved tissues from 9- to 11-year-old male Indianorigin rhesus macaques that had previously undergone necropsy following various malaria challenges or BCG vaccination protocols (Online Resource 1).

Livers were processed as previously described (Epstein et al. 2011). Spleen and lymph nodes were dissociated by passing tissue through a $70-\mu \mathrm{m}$ cell strainer using a $6-\mathrm{mL}$ syringe plunger. Splenocytes were further separated by Ficoll gradient centrifugation. Lung tissue was processed in a GentleMacs Dissociator (Miltenyi Biotec, Bergisch Gladbach, Germany) according to manufacturer's instructions including enzymatic digestion (collagenase I/DNAse) for $30 \mathrm{~min}$ in $37{ }^{\circ} \mathrm{C}$ with shaking at $200 \mathrm{rpm}$. All cells were cryopreserved in 10\% DMSO/FCS and stored in liquid nitrogen until use.

\section{Generation of human CD1D tetramers}

PBS-57 ( $\alpha$-galactosylceramide or $\alpha$-GalCer)-loaded and unloaded human CD1D monomers were provided by the National Institutes of Health Tetramer Core Facility (Emory University, Atlanta, GA). Tetramers were prepared as previously described (Liu et al. 2006). Briefly, $10 \mu \mathrm{L}$ of the loaded or unloaded stock monomers was incubated with $19 \mu \mathrm{L}$ of streptavidin conjugated to APC (Life Technologies, Carlsbad, CA), PE (Life Technologies, Carlsbad, CA), DyLight 488 (Thermo Fisher Scientific, Rockford, IL), or BV650 (BioLegend, San Diego, CA) that were titrated in at ten aliquots of $1.9 \mu \mathrm{L}$ every $10 \mathrm{~min}$ to facilitate tetramerization. The tetramer was filtered through a SpinX column (Sigma, St. Louis, MO) to remove aggregates and stored at $4{ }^{\circ} \mathrm{C}$ until use.

\section{Culture media}

Media (R10) for washing PBMC consisted of RPMI 1640 (Gibco, Waltham, MA) supplemented with $10 \%$ fetal bovine serum (FBS) (Hyclone, Logan, UT). Our base T cell media (TCM) consisted of RPMI 1640 supplemented with $10 \%$ FBS, $100 \mathrm{U} / \mathrm{mL}$ penicillin, $100 \mathrm{mg} / \mathrm{mL}$ streptomycin, $55 \mathrm{mM}$ 2-mercaptoethanol, $0.3 \mathrm{X}$ essential amino acids, $60 \mathrm{mM}$ non-essential amino acids, $11 \mathrm{mM}$ HEPES, and 800 mM L-glutamine (Gibco, Waltham, MA) sterile-filtered. Our TCM containing human serum (TCM/HS) consisted of $10 \%$ human serum (derived from healthy donors), $100 \mathrm{U} / \mathrm{mL}$ penicillin, $100 \mathrm{mg} / \mathrm{mL}$ streptomycin, and $400 \mathrm{mM} \mathrm{L}$ glutamine (Gibco, Waltham, MA). Enhanced RPMI for Jurkat cell culturing consisted of RPMI 1640 (Gibco, Waltham, MA) supplemented with 10\% FBS (Hyclone, Logan, UT), 800 mM L-glutamine (Gibco, Waltham, MA), 
$100 \mathrm{U} / \mathrm{mL}$ penicillin, and $100 \mathrm{mg} / \mathrm{mL}$ streptomycin (Gibco, Waltham, MA).

\section{Tetramer staining}

Rhesus PBMC were thawed in warm thaw media (R10 with $2 \mu \mathrm{L} / \mathrm{mL}$ Benzonase (Millipore, Billerica, MA) sterile-filtered) and centrifuged at $1500 \mathrm{rpm}$ for $5 \mathrm{~min}$. The supernatant was decanted, and the viable cells were enumerated by trypan blue (Millipore, Billerica, MA) exclusion. The cells were centrifuged at $1500 \mathrm{rpm}$ for $5 \mathrm{~min}$ and rested overnight at a density of 2 million cells $/ \mathrm{mL}$. The following day, the cells were counted and plated at a density of 1 million cells/well in a 96well U-bottom plate. The cells were washed with FACS buffer (1× phosphate-buffered saline (PBS) (Gibco, Waltham, MA) supplemented with $0.2 \%$ bovine serum albumin (BSA) (Sigma, St. Louis, MO)) and centrifuged at $1800 \mathrm{rpm}$ for 3 min. They were then blocked with human serum (Valley Biomedical, Winchester, VA) and FACS buffer mixed 1:1 for $10 \mathrm{~min}$ at $4{ }^{\circ} \mathrm{C}$. The wells were washed twice with FACS buffer and then resuspended in $50 \mu \mathrm{L}$ FACS buffer with $4 \mu \mathrm{L}$ of either unloaded CD1D tetramer or $\alpha$-GalCer-loaded CD1D tetramer and incubated at room temperature for $40 \mathrm{~min}$ in the dark. At the end of the incubation period, the cells were washed twice with PBS and stained with Aqua Live/Dead stain (Life Technologies, Carlsbad, CA) according to the manufacturer's instructions. Following a 15-min incubation at room temperature, the cells were washed twice in PBS and then labeled with anti-CD3 PerCP Cy5.5 (clone SP34-2) (BD Biosciences, San Jose, CA), anti-CD4 APC H7 (clone L200) (BD Biosciences, San Jose, CA), and anti-CD8 $\alpha$ BV650 (clone RPA-T8) (BioLegend, San Diego, CA) antibodies for $30 \mathrm{~min}$ at $4{ }^{\circ} \mathrm{C}$. After two final washes in FACS buffer, the cells were fixed in 1\% paraformaldehyde (PFA) (Electron Microscopy Sciences, Hatfield, PA) and acquired on a BD LSRFortessa (BD Biosciences, San Jose, CA) equipped with blue $(488 \mathrm{~nm})$, green $(532 \mathrm{~nm})$, red $(628 \mathrm{~nm})$, violet $(405 \mathrm{~nm})$, and ultraviolet $(355 \mathrm{~nm})$ lasers.

\section{T cell sorting and expansion}

Rhesus macaque PBMC were thawed and rested as described above and counted using trypan blue. The following day, the cells were stained with tetramer as described in "Materials and methods" but were resuspended in TCM rather than fixed with $1 \%$ PFA. The cells were filtered through a cell strainer tube (Falcon, Tewksbury, MA) prior to sorting to remove aggregates, and tetramer-positive T cells were collected at the UW Department of Immunology Flow Cytometry Core using a FACS Aria (BD Biosciences, San Jose, CA) cell sorter equipped with violet (407 nm), blue (488 nm), and red $(641 \mathrm{~nm})$ lasers.
Sorted T cells were washed and resuspended in TCM/HS. They were then divided between eight wells of a 96-well Ubottom tissue culture plate and seeded with 150,000 cells per well of irradiated human PBMC as feeder cells. Phytohemagglutinin (PHA) (Remel, San Diego, CA) was added to a final concentration of $1.6 \mathrm{mg} / \mathrm{mL}$. After 2 days in culture at $37^{\circ} \mathrm{C} / 5 \% \mathrm{CO}_{2}, 10 \mu \mathrm{L}$ human natural IL-2 (hnIL-2) (Hemagen, Columbia, MD) was added to each well. Half the media was replaced every 2 days with TCM/HS supplemented with 1:20 hnIL-2. When the cell clusters were large and round (approximately after 8 days of growth), they were pooled into a 24-well plate. After 10 days in culture, cell lines were screened by CD1D- $\alpha$-GalCer tetramer staining as described above. Further expansion of the $\mathrm{T}$ cell line was performed using a modified version of a previously established rapid expansion protocol (Riddell et al. 1992). Briefly, 100,000 T cells were mixed with 5 million irradiated EBV-transformed B cells and 25 million irradiated PBMC as feeder cells in R10 in T25 tissue culture flasks (Costar, St. Louis, MO) with $25 \mathrm{~mL}$ TCM. Anti-CD3 (clone OKT3) was added at a final concentration of $30 \mathrm{ng} / \mathrm{mL}$, and the mixture was incubated overnight at $37{ }^{\circ} \mathrm{C} / 5 \% \mathrm{CO}_{2}$. The following day, recombinant human IL2 (rhIL-2) (Prometheus Pharmaceuticals through UWMC Clinical Pharmacy) was added at a final concentration of $50 \mathrm{U} / \mathrm{mL}$. On day 4, the cells were washed twice in TCM to remove the anti-CD3 antibody and resuspended in fresh media supplemented with rhIL-2 at $50 \mathrm{U} / \mathrm{mL}$. Half the media was replaced every 3 days or split into new T25 tissue culture flasks as determined by cell confluency. After 13 days in culture, the line was screened by tetramer staining and then cryopreserved on day 14 .

\section{Intracellular cytokine staining}

$\mathrm{T}$ cell lines were thawed and rested as described above. In parallel, 250,000 K562 antigen-presenting cells stably transfected with human CD1D (courtesy of D. Branch Moody, Brigham and Women's Hospital) were loaded with $5 \mu \mathrm{g} / \mathrm{mL} \alpha$-GalCer (Avanti Polar Lipids, Alabaster, Alabama) per well for $18 \mathrm{~h}$ at $37{ }^{\circ} \mathrm{C} / 5 \% \mathrm{CO}_{2}$. The next day, the cells were centrifuged at $1800 \mathrm{rpm}$ for $3 \mathrm{~min}$, and 1 million cells per well were plated into a 96-well U-bottom plate. Stimulation was performed at $37{ }^{\circ} \mathrm{C} / 5 \% \mathrm{CO}_{2}$ for $6 \mathrm{~h}$ in the presence of 200,000 $\alpha$-GalCer-loaded or control K562-CD1D cells and $10 \mu \mathrm{g} / \mathrm{mL}$ Brefeldin A (Sigma, St. Louis, MO). At the end of the incubation period, EDTA (Thermo Fisher Scientific, Waltham, MA) at a final concentration of $2 \mathrm{mM}$ was added, and the plates were stored overnight at $4{ }^{\circ} \mathrm{C}$. The following day, the samples were washed twice in PBS and then stained with Aqua Live/Dead (Life Technologies, Carlsbad, CA) prepared according to manufacturer's instructions and incubated for $20 \mathrm{~min}$ at room temperature. Live/ Dead staining and all steps following were performed in the 
dark. The cells were washed twice in PBS and then incubated at room temperature for $10 \mathrm{~min}$ in $1 \times$ FACS Lyse (BD Biosciences, San Jose, CA). Following one wash with FACS buffer, the cells were incubated an additional $10 \mathrm{~min}$ in $1 \times$ FACS Perm II (BD Biosciences, San Jose, CA) at room temperature. The cells were washed twice in FACS buffer and stained with markers for CD3, CD4, CD $8 \alpha$, IFN- $\gamma$ (clone B27) (BD Biosciences, San Jose, CA), and TNF (clone Mab11) (eBioSciences, Waltham, MA) for $30 \mathrm{~min}$ at $4{ }^{\circ} \mathrm{C}$. Following two final washes in FACS buffer, the cells were fixed in 1\% PFA and acquired on a BD LSRFortessa (BD Biosciences, San Jose, CA).

\section{T cell receptor cloning and sequencing}

RNA was extracted from rhesus-derived iNKT cell lines using a RNeasy Mini Kit (Qiagen, Hilden, Germany). cDNA was generated from $1 \mu \mathrm{g}$ RNA using the SMARTer RACE 5'/3' Kit (Clontech Laboratories, Inc., Mountain View, CA) and the manufacturer's protocol for preparing 5'-RACE-Ready cDNA.

To determine the sequence of the rhesus $\mathrm{T}$ cell receptor (TCR)- $\beta$ chain, 5'-RACE was performed according to the manufacturer's protocol using the following gene-specific primer for the human TCR- $\beta$ chain constant region: $5^{\prime}-$ GATTACGCCAAGCTTCCCATTCACCCACCAGC TCAGCTCCACG-3'. The RACE products were resolved through a $1 \%$ agarose (Thermo Fisher Scientific, Waltham, MA) gel supplemented with $1 \times$ SYBR Safe (Life Technologies, Carlsbad, CA) for $1 \mathrm{~h}$ at $120 \mathrm{~V}$, and the band located at $\sim 700$ bp was excised. The NucleoSpin Gel and PCR Clean-up kit (Macherey-Nagel, Duren, Germany) was used to extract DNA, and then In-Fusion Cloning of RACE Products was performed according to the 5'-RACE protocol according to manufacturer's instructions. Plasmid DNA was extracted using the Plasmid Mini Kit (Qiagen, Hilden, Germany) and was submitted for sequencing (Genewiz, South Plainfield, NJ).

To determine the sequence of the rhesus TCR- $\alpha$ chain, primers for the human iNKT TCR- $\alpha$ chain constant region (5'-GATTACGCCAAGCTTGTTGCTCCAGGCCACAG CACTGTTGCTC-3') and for rhesus V $\alpha 24$ (TRAV10) (5'ATGAAGAAGCGTCTGAGGACC-3') were used. PCR was performed using Q5 High-Fidelity DNA Polymerase (New England BioLabs, Ipswich, MA) according to the manufacturer's instructions. The PCR product was resolved through a $1 \%$ agarose gel supplemented with $1 \times$ SYBR Safe, and the band located at $\sim 600 \mathrm{bp}$ was excised. DNA was extracted using the NucleoSpin Gel and PCR Clean-up kit and sequenced. The sequencing results for both TCR- $\alpha$ and TCR- $\beta$ were cleaned using Sequencher software version 5.2.4 and analyzed using the IMGT/V-QUEST program version 3.4.7. Sequences were aligned using Serial Cloner version 2.6 .
Modeling of the rhesus NKT and CD1D

Rhesus macaque CD1D-NKT interactions were modeled based on the crystal structure of the human orthologs (PDB 2po6). Using open-source PyMOL (The PyMOL Molecular Graphics System, version 1.8.61 Schrödinger, LLC), residues with nonsynonymous substitutions were mutated in silico with the lowest energy rotamer. Residues were subsequently colored based on predicted interactions with CD1D (blue), nonsynonymous mutations with conserved biochemical properties (green), and nonsynonymous mutations with differing biochemical properties (red).

\section{T cell receptor reconstitution}

\section{T cell receptor cassette construction}

Codon-optimized rhesus-derived iNKT cell TCR sequences were assembled into a TCR cassette (Linnemann et al. 2013). In this construct, the TCR- $\alpha$ and TCR- $\beta$ chain constant regions are replaced with modified murine TCR constant regions to facilitate measurement of TCR expression and to encourage pairing between exogenous TCR chains. The TCR cassettes were synthesized through Thermo Fisher GeneArt Synthesis service and were then cloned into pRRL.PPT.MP.GFPpre (Jing et al. 2016; Zhou et al. 2012) using BamHI and SalI restriction enzymes (New England BioLabs, Ipswich, MA). All plasmids were purified using Maxi Prep kits (Qiagen, Hilden, Germany).

\section{Generation of lentivirus}

Lenti-X HEK293T cells (Clontech, Mountain View, CA) were seeded at 2 million cells per $100 \mathrm{~mm}$ tissue culture dish and incubated for $48 \mathrm{~h}$ at $37{ }^{\circ} \mathrm{C} / 5 \% \mathrm{CO}_{2}$ in DMEM (Gibco, Waltham, MA) or until cells reached $75 \%$ confluency. The medium was replaced $4 \mathrm{~h}$ before transfection. Cells were transfected with $10 \mu \mathrm{g}$ pRRL-TCR plasmid, $5 \mu \mathrm{g}$ pCIVSVG envelope plasmid, and $5 \mu \mathrm{g}$ of a psPAX2 packaging vector (gifted from Dr. Stanley Riddell at Fred Hutchinson Cancer Research Center). Plasmids were mixed with Fugene 6 transfection reagent (Promega, Madison, WI) at a dilution of 1:12 in a total volume of $600 \mu \mathrm{L}$. Transfection mixture was added dropwise into the cell culture and incubated overnight in the conditions described above. The medium was then replaced and incubated for an additional $48 \mathrm{~h}$. After this time, $20 \mu \mathrm{L}$ of supernatant was titered using Lenti-X GoStix (Clontech, Mountain View, CA) per the manufacturer. Supernatant was then harvested every $12 \mathrm{~h}$ for a total of three collections. At each collection, cell debris was removed by centrifugation at $1500 \mathrm{rpm}$ for $5 \mathrm{~min}$, and cleaned supernatant was reserved in a $50-\mathrm{mL}$ conical and kept at $4{ }^{\circ} \mathrm{C}$ until three collections had been acquired. Supernatant was then 
incubated overnight with Lenti-X concentrator (Clontech, Mountain View, CA) at a ratio of 1:3. The following day, the supernatant was centrifuged at $1500 \times \mathrm{g}$ for $45 \mathrm{~min}$ at $4{ }^{\circ} \mathrm{C}$. Supernatant was then discarded, and the pelleted virions were resuspended in $300 \mu \mathrm{L}$ R 10 media and stored at $-80^{\circ} \mathrm{C}$ until further use.

\section{Transduction of Jurkat cells}

CD8-expressing Jurkat cells were seeded at 1 million cells per well in a 48-well plate in enhanced RPMI. The same day, the Jurkat cells were transduced with TCR lentivirus at an estimated multiplicity of infection (MOI) of 5 with $1 \mu \mathrm{L}$ of polybrene at a final concentration of $4 \mu \mathrm{g} / \mathrm{mL}$ (Sigma, St. Louis, MO). Cells and virus were incubated for $4 \mathrm{~h}$ at $37{ }^{\circ} \mathrm{C} / 5 \% \mathrm{CO}_{2}$ and washed with PBS (Gibco, Waltham, $\mathrm{MA})$ to remove excess virus. Jurkat cells were maintained in culture for 1 week using enhanced RPMI and screened for TCR expression (Jing et al. 2016) using an anti-mouse TCR- $\beta$ chain APC antibody (BD Biosciences, San Jose, $\mathrm{CA}$ ) and tetramer staining as described above.

\section{Multiparameter flow cytometry}

To determine the phenotypes of iNKT cells present in blood and tissue, the following samples were analyzed in two batches: PBMC $(n=12)$, lung $(n=5)$, lymph node $(n=9)$, spleen $(n=9)$, and liver $(n=4)$ (Online Resource 1$)$. Cryopreserved cells were thawed in warm $\left(37^{\circ} \mathrm{C}\right) \mathrm{R} 10$ medium and centrifuged at $1500 \mathrm{rpm}$ for $7 \mathrm{~min}$. Between 1 and 5 million cells per well were plated in a 96-well V-bottom plate and were washed twice with FACS buffer and centrifuged at $2000 \mathrm{rpm}$ for $3 \mathrm{~min}$. They were then resuspended in $50 \mu \mathrm{L}$ tetramer staining buffer with a pre-titrated amount of PBS-57 $(\alpha$-GalCer)-loaded CD1D tetramer (NIH Tetramer Core Facility, Emory University, Atlanta, GA) and incubated at room temperature for $20 \mathrm{~min}$ protected from light. Cells were washed three times with PBS and stained with Ultraviolet Live/Dead stain (Life Technologies, Carlsbad, CA) for $20 \mathrm{~min}$ at room temperature. Cells were washed twice in FACS buffer and then immunostained with a cocktail of cell surface antibodies (Online Resource 2) for $20 \mathrm{~min}$ at room temperature. Following three washes with surface staining buffer, cells were fixed in 1\% PFA (Electron Microscopy Sciences, Hatfield, PA) and acquired on a BD FACSymphony X-50 (BD Biosciences, San Jose, CA) equipped with blue $(488 \mathrm{~nm})$, green $(532 \mathrm{~nm})$, red $(628 \mathrm{~nm})$, violet $(405 \mathrm{~nm})$, and ultraviolet $(355 \mathrm{~nm}$ ) lasers.

Analysis was performed in FlowJo version 9.9.6. For Fig. $4 \mathrm{~b}$, the R openCyto "mindensity" function was used to gate all populations after the viability gate (e.g., Live $>\mathrm{CD}^{+}>\mathrm{Tet}^{+}$) (Finak et al. 2014).

\section{Results}

\section{A five-gene CD1 locus is evolutionarily conserved among primates}

To explore the evolution of CD1 genes in primates, we constructed a gene tree of simian primate $\mathrm{CD} 1$ sequences, rooted against the chicken CD1 locus (Fig. 1). Remarkably, except for CD1A in olive baboon, each paralog exists as a single-gene copy in each primate species and forms a phylogenetically distinct group that generally matches the species phylogeny. From both these results and further examination of additional mammalian CD1 sequences (data not shown), CD1D appears to be the ancestral CD1 paralog. Through additional gene duplication events, CD1E likely arose next, followed by the other "Group 1" CD1 genes (CD1A, CD1B, and CD1C). These data broadly reveal that the CD1 gene cluster is highly conserved over 45 million years of primate evolution, which stands in stark contrast to the evolution of MHC class I over this same time period.

\section{Human CD1D tetramers identify iNKT cells in rhesus macaques}

This genetic analysis and published studies demonstrating the use of human CD1D tetramers in sooty mangabeys led us to hypothesize that we could use human CD1D tetramers to isolate invariant NKT cells from rhesus macaques (Rout et al. 2012, 2010b). We used human CD1D tetramers loaded with $\alpha$-GalCer to stain peripheral blood mononuclear cells from a healthy rhesus macaque and noted a distinct population of $\mathrm{T}$ cells bound to tetramer with a fluorescence intensity similar to that seen in humans (Fig. 2a). We further noted that tetramerbound cells primarily expressed $\mathrm{CD} 8 \alpha$ in rhesus macaques but were $\mathrm{CD}^{+}$and $\mathrm{CD} 4^{-} \mathrm{CD} 8^{-}$in humans (Fig. 2a). These data extend previous studies in rhesus macaques using TCR- $\alpha$-specific monoclonal antibodies (Gansuvd et al. 2008, 2003). To confirm the specificity of this staining, we sorted the tetramer-positive cells and expanded them in vitro for 4 weeks. The resulting $\mathrm{T}$ cell line consisted of $97 \%$ tetramer-bound cells with staining intensity similar to that observed in a human $\mathrm{T}$ cell line (Fig. 2b). We next sought to investigate whether rhesus-derived iNKT cells could generate a functional response to antigen presented by human CD1D. We co-incubated iNKT cells with K562 antigen-presenting cells stably transfected with human CD1D and pre-loaded with $\alpha$-GalCer. Rhesus-derived iNKT cells produced IL-2, IFN- $\gamma$, and TNF only in the presence of $\alpha$-GalCer and CD1D (Fig. 2c). Taken together, these data confirm and significantly extend previous studies by revealing that iNKT cells in rhesus macaques can be isolated using human CD1D tetramers and are activated by human CD1D transfectants. 


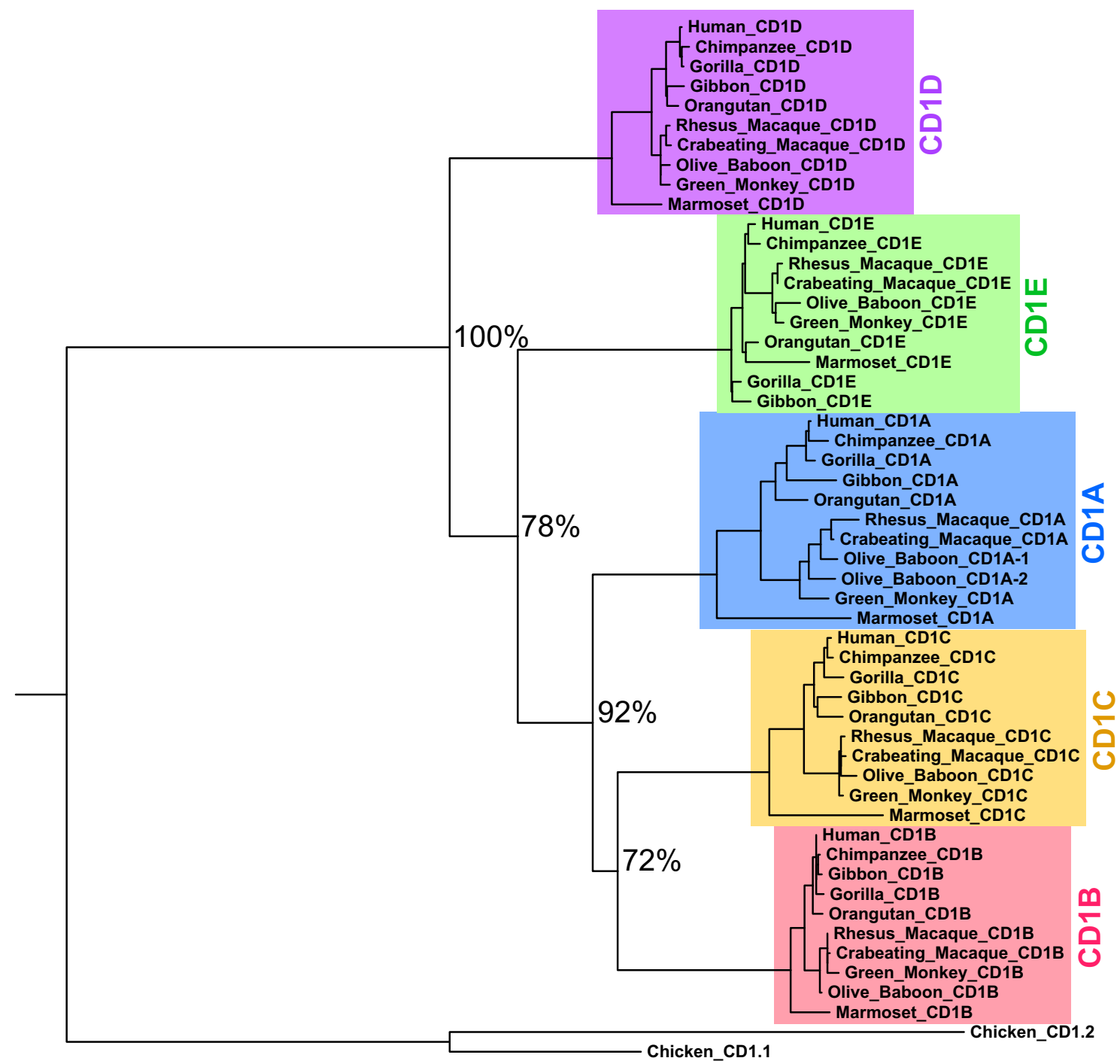

Fig. 1 Conservation of the CD1 primate locus. Primate CD1 homolog sequences were acquired from a combination of bioinformatic sources. A maximum likelihood $\mathrm{CD} 1$ gene tree was constructed after including two chicken homologs for rooting. Apart from CD1A in olive baboon, each paralog exists as a single gene copy in each primate species and forms a

\section{Human and non-human primate iNKT cell T cell receptor sequences are highly conserved}

Next, we sought to define the molecular requirements for antigen recognition by iNKT cells in rhesus macaques. Published data suggest that the invariant TCR- $\alpha$ uses the same variable (TRAV10) and joining (TRAJ18) genes as the human iNKT cell TCR, but the composition of the TCR- $\beta$ chain has not been determined (Kashiwase et al. 2003). We used PCR and template-switched PCR to clone the dominant TCR- $\alpha$ and TCR- $\beta$ respectively from our rhesus-derived iNKT cell line (Table 1). We found that the TCR- $\alpha$ consisted of a germline rearrangement of TRAV10 and TRAJ18 with CDR3 $\alpha$ amino acid sequence that was virtually identical to that observed in humans (Dellabona et al. 1994; Porcelli 1993). Specifically, phylogenetically distinct group that generally matches the species phylogeny (bootstrap probabilities are reported as percentages for separation of each paralog group). CD1D is likely the oldest gene and shows the most conservation among primate species

we noted that residues known to be important for binding $\alpha$ GalCer-loaded CD1D were highly conserved except for a single conservative substitution located in the CDR3 $\alpha$ (Table 1, Fig. 3a) (Borg et al. 2007). Importantly, sequence variants located outside of the CDR $3 \alpha$ provided confirmation that the cloned TCR was indeed derived from rhesus macaque and not from contaminating human DNA template (Table 1). These data led us to consider whether the germline-encoded gene segments constituting the invariant TCR- $\alpha$ were conserved across primate species. We extracted TRAV10 and TRAJ18 gene segments from the genomes of ten simian primates studied above and performed sequence alignment. We noted two clusters broadly dividing into human and Old World monkeys in one cluster and New World monkeys in the other cluster (Fig. 3b). In all species, the CDR $1 \alpha$ and 


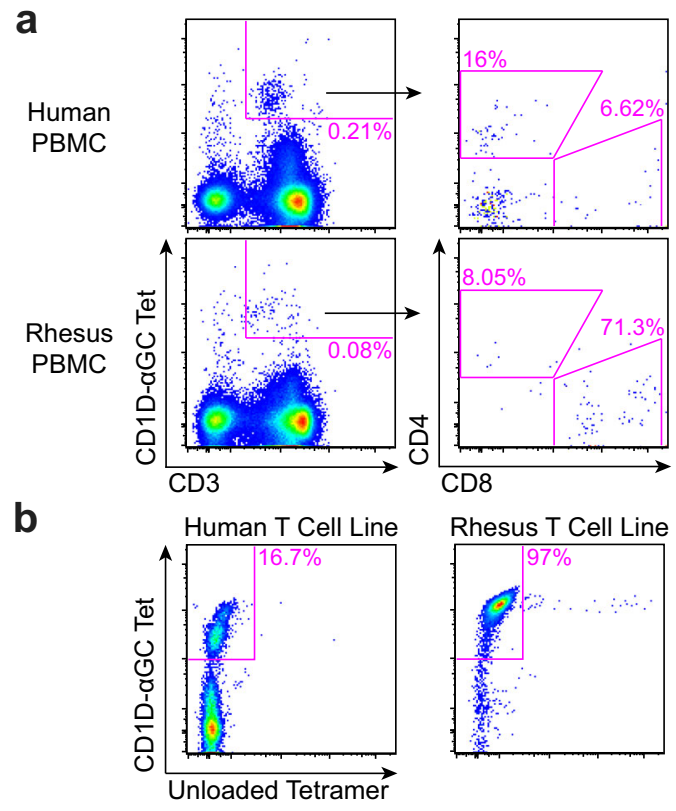

Fig. 2 Rhesus iNKT cells stain with human $\alpha$-GalCer-loaded CD1D tetramers and are activated by human CD1D-transfected antigen-presenting cells. a The frequency of $\alpha$-GalCer-specific T cells was identified as $\mathrm{CD}^{+}$and CD1D- $\alpha-$ GalCer tetramer positive (CD1D-aGC Tet $\left.{ }^{+}\right)$. Shown is representative staining from a rhesus macaque (bottom) and human PBMC (top). Tetramer-positive cells were further examined for expression of CD4 or CD8 $\alpha$ co-receptor. b CD1D-aGC Tet ${ }^{+}$cells were sorted and expanded in vitro after which the $\mathrm{T}$ cell lines were screened with tetramer to determine specificity for $\alpha$-GalCer. c Human K562 cells that

CDR $3 \alpha$ sequences, which are known to be critical for binding $\alpha$-GalCer and CD1D, were highly conserved. Together with the data presented in Fig. 1, these data suggest purifying natural selection on the genes required for lipid antigen presentation and recognition in primates.

We found the dominant TCR- $\beta$ rearrangement to consist of TRBV25 and TRBJ2, which is precisely what is observed in the canonical iNKT cell TCR in humans (Dellabona et al. 1994; Porcelli 1993). However, there was a conservative (K57R) (denoting the human residue, the residue number,
C
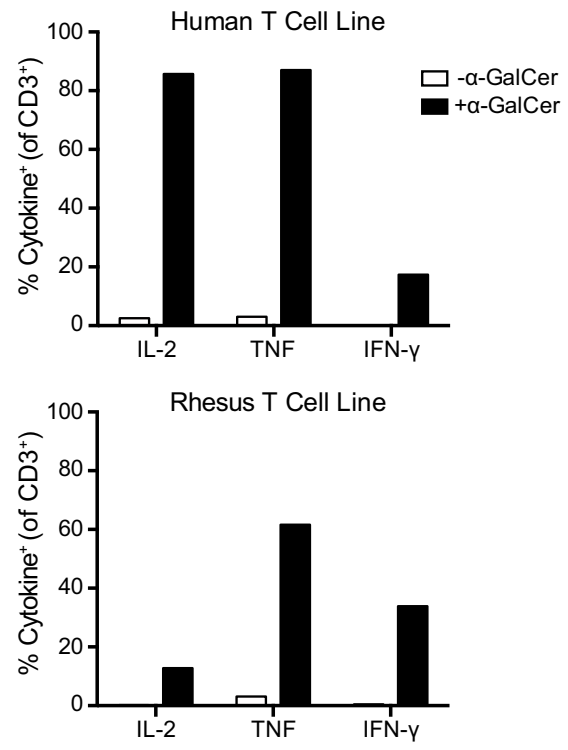

were stably transfected with human CD1D were co-incubated with iNKT cells in the presence or absence of $\alpha$-GalCer. Intracellular cytokine analysis shows that cells produce IL-2, TNF, and IFN- $\gamma$ in the presence of human CD1D and $\alpha$-GalCer. Data are expressed as percent cytokine positive of $\mathrm{CD}^{+}$cells. Sorting and T cell line data are representative of one rhesus macaque, but tetramer staining of T cells and the iNKT cell line was confirmed in at least two experiments. Intracellular cytokine staining was performed twice on the iNKT cell line, and a representative graph is shown

then the rhesus macaque residue) and an aliphatic to aromatic (L60F) substitution in the CDR2 $\beta$. Further, the CDR3 $\beta$ sequence was only 12 amino acids in length compared to 18 amino acids in humans (Table 1). We modeled the effect of these differences on the human iNKT cell TCR-CD1D- $\alpha$ GalCer co-crystal structure (Fig. 3a) (Borg et al. 2007). Dynamic modeling studies indicated that this difference might influence the molecular interactions with human CD1D- $\alpha$ GalCer. To directly test this hypothesis, we transduced the rhesus iNKT TCR into Jurkat cells and attempted to stain
Table 1 iNKT TCR- $\alpha$ and TCR$\beta$ gene segment usage and sequences for human and rhesus macaque with differences in italics

\begin{tabular}{llll}
\hline & & Human & Rhesus Macaque \\
\hline TCR- $\alpha$ & Variable & TRAV10*01 & TRAV10*01 \\
& CDR1 & VSPFSN & VSPFSN \\
& CDR2 & MTFSENT & MTFSENT \\
& CDR3 & CVVSDRGSTLGRLYF & CVVSDRGSTLGKLYF \\
& Joining & TRAJ18*01 & TRAJ18*01 \\
TCR- $\beta$ & Variable & TRBV25- $1 * 01$ & TRBV25- $1 * 01$ \\
& CDR1 & MGHDK & MGHDK \\
& CDR2 & SYGVNS & SYGVNS \\
& CDR3 & CASSEEGALKESVGTQYF & CASSDPDNEQFF \\
& Joining & TRBJ2-3*01 & TRBJ2- $1 * 02$ \\
\hline
\end{tabular}


a

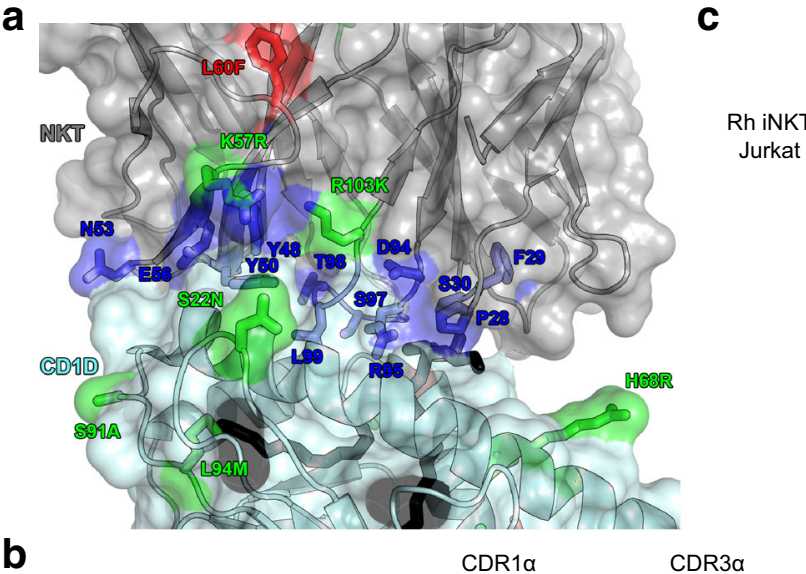

C

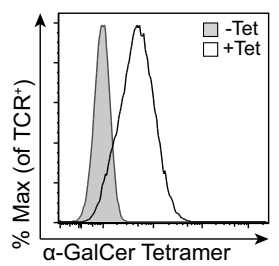

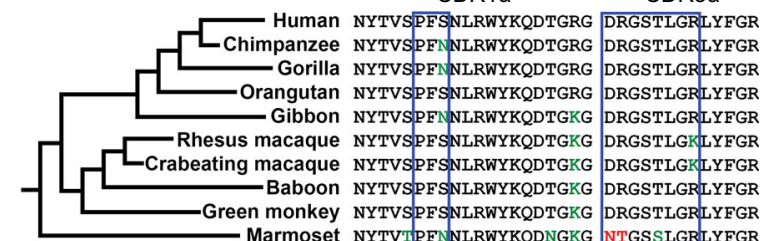

Fig. 3 The human and non-human primate iNKT cell TCR is highly conserved. a Modeling of rhesus macaque CD1D-NKT interactions based on the crystal structure of the human orthologs (PDB 2po6). $\alpha$ GalCer (black) is shown loaded onto CD1D (light blue). Residues with nonsynonymous substitutions were mutated in silico with the lowest energy rotamer. Residues were subsequently colored based on expected interactions with CD1D (royal blue), nonsynonymous mutations with conserved biochemical properties (green), and nonsynonymous mutations with differing biochemical properties (red). b The TRAV10 CDR $1 \alpha$ and TRAJ 18 CDR $3 \alpha$ gene segments that are present as a

the cells with human CD1D tetramer. Only CD1D tetramer loaded with $\alpha$-GalCer, and not mock-loaded tetramer, was able to successfully stain the Jurkat transductants (Fig. 3c). These data reveal that a highly conserved "pan-primate" iNKT TCR is necessary and sufficient for binding $\alpha$ GalCer-loaded human CD1D tetramer.

\section{Non-human primate iNKT cells express diverse tissue phenotypes}

Finally, we used human CD1D tetramers to characterize the ex vivo frequencies and phenotypes of iNKT cells in peripheral blood and tissues of 12 rhesus macaques that had undergone necropsy after malaria challenge or BCG vaccination (Fig. 4a). We incorporated $\alpha$-GalCer-loaded CD1D tetramers into a 20-color flow cytometry panel designed to measure coreceptor usage (CD4, CD8), memory status (CD45RA, CCR7, CD28, CD127), activation (CD69, CD161, HLADR, PD-1, NKG2A), and TCR- $\gamma \delta$ usage (pan- $\gamma \delta, \mathrm{V} \gamma 9$, V81) (Online Resource 2). In seven animals, iNKT cells were rare or undetectable in both blood and tissue (Fig. 4b). We defined iNKT cell phenotypes in 17 samples derived from five animals with clearly distinguished populations of tetramerpositive cells (Online Resource 3). Most iNKT cells from germline rearrangement in iNKT cells were examined across the genomes of ten simian primates, and sections crucial for binding are boxed. Residues important for TCR binding to CD1D and $\alpha$-GalCer are shown in blue and are highly conserved. Conservative mutations are shown in green, and non-conservative substitutions in red. $\mathbf{c}$ The rhesus iNKT TCR was transduced into Jurkat cells and stained with human CD1D- $\alpha$-GalCer or control tetramer. Data are expressed as percent tetramer-positive events of anti-mouse TCR-positive cells and are representative of at least three independent experiments

these 17 samples expressed a $\mathrm{CD} 45 \mathrm{RA}^{-} \mathrm{CCR} 7^{\mathrm{lo}} \mathrm{CD} 28^{+}$effector memory phenotype while CD127 was generally not detected (Online Resource 4a-c). Consistent with the published literature, we found that iNKT cells in the blood of rhesus macaques predominantly expressed the CD8 co-receptor in contrast to human iNKT cells (Fig. 4c) (Chen et al. 2009; Kawashima et al. 2003). Expression of CD8 was also dominant in all of the tissue samples except the spleen of rhesus \#11 in which all the iNKT cells expressed CD4. Further investigation revealed that these cells were $\gamma \delta \mathrm{T}$ cells expressing $\mathrm{V} \gamma 9$ and V $\delta 1$ gene segments (Online Resource 4d-g). iNKT cells observed in spleens of three other animals were not found to contain $\gamma \delta$-expressing iNKT cells (Online Resource 4d). We were unable to detect iNKT cells above background in the spleens of five other animals (Online Resource 3). Next, we examined expression of CD161, which has been reported to be universally absent on blood iNKT cells in rhesus macaques but present on blood iNKT cells in humans (Exley et al. 1998; Gansuvd et al. 2003). We found that CD161 was indeed expressed by tissue-resident iNKT cells, and low staining was also observed in PBMC of some animals, challenging the current paradigm (Fig. 4d). CD69 was also more highly expressed by tissue-resident iNKT cells compared to those in blood (Fig. $4 \mathrm{e})$. Finally, we examined the expression of activation marker 


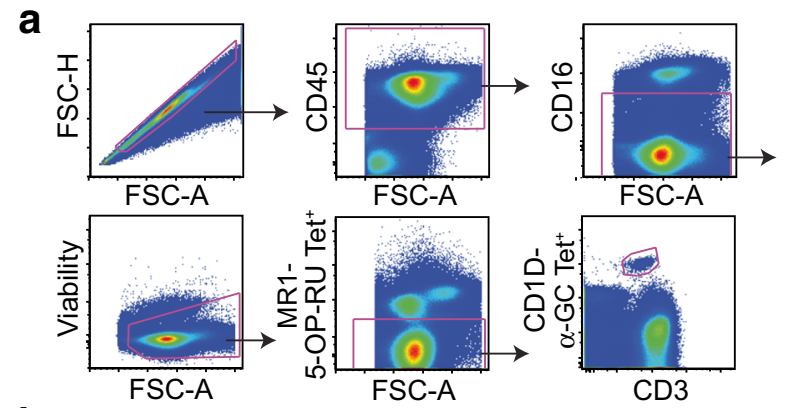

b

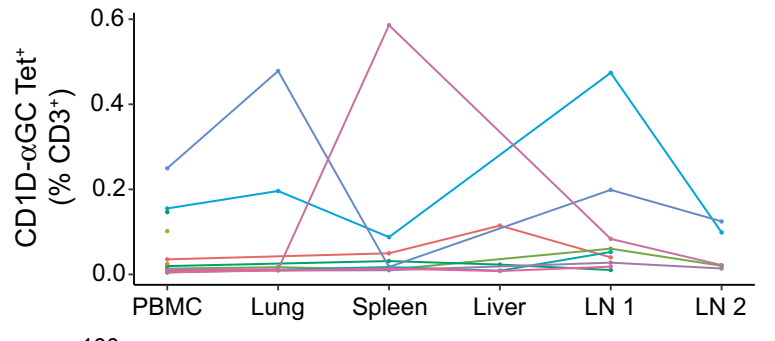

C

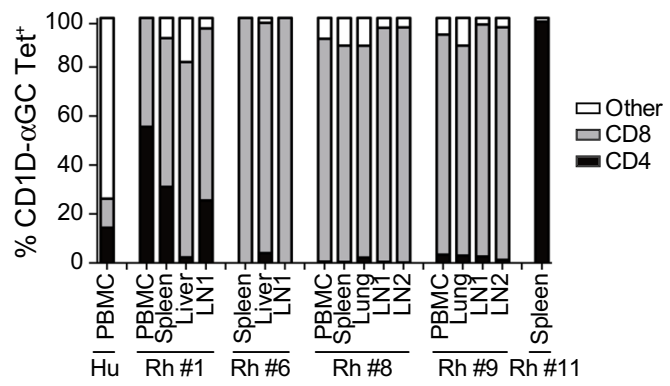

Fig. 4 Tissue phenotypes of iNKT cells in rhesus macaques. PBMC and tissues from healthy rhesus macaques $(\mathrm{Rh})$ were stained with human $(\mathrm{Hu})$ $\alpha$-GalCer-loaded CD1D tetramers (CD1D-aGC Tet). a Gating strategy for identifying iNKT cells from rhesus macaque blood and tissue samples proceeds from singlets to $\mathrm{CD} 45^{+}$cells (pan leukocytes) to $\mathrm{CD} 16^{-}$cells to remove NK cells. Viable cells were then identified, and MR1-5-OP-RU tetramer was used to exclude MAIT cells. Finally, CD $3^{+} \mathrm{CD} 1 \mathrm{D}-\alpha \mathrm{GC} \mathrm{Tet}^{+}$ cells were identified. b Frequency of iNKT cells in PBMC and associated

HLA-DR and inhibitory marker PD-1, which were generally absent on iNKT cells in blood and tissue (Online Resource 4hi). However, the inhibitory marker NKG2A was highly expressed in the spleens of three animals while being absent in the blood (Fig. 4f). Taken together, these data reveal that iNKT cells in rhesus macaques express diverse tissue phenotypes that are not always apparent in peripheral blood.

\section{Discussion}

In summary, we performed a detailed evolutionary analysis of primate $\mathrm{CD} 1$ genes and found remarkable conservation across the five genes constituting the human locus, which is the best studied. We also show that molecular interactions between CD1D and the iNKT TCR are highly conserved between humans and rhesus macaques, and that this likely extends to other non-human primate species as well. Finally, we discovered diverse tissue phenotypes of iNKT cells in rhesus
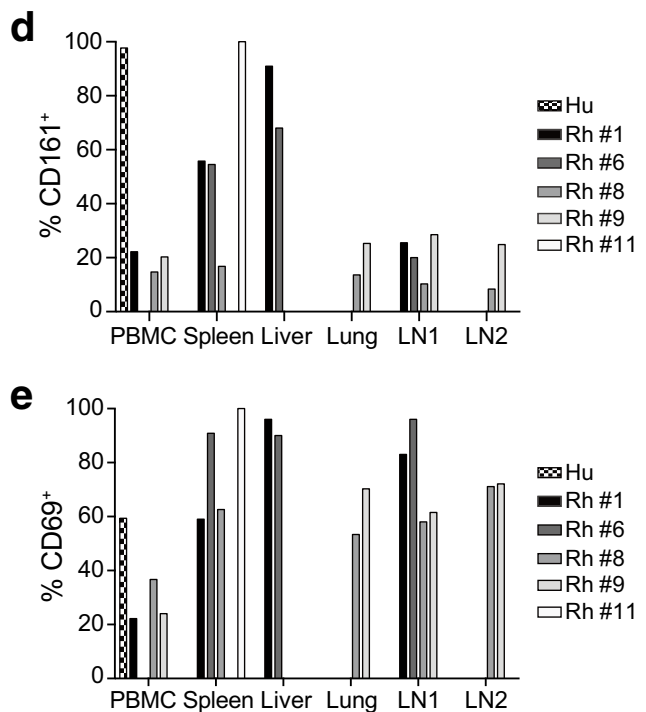

f

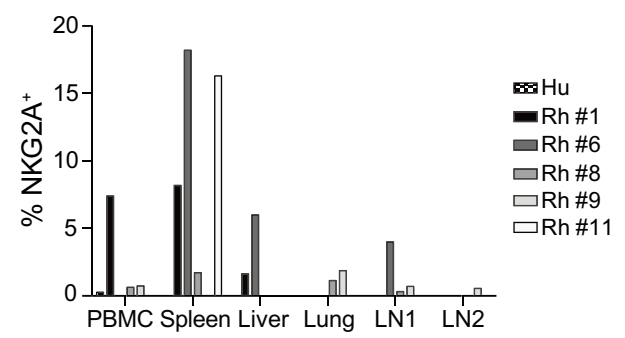

tissues from 12 rhesus macaques following staining with CD1D- $\alpha$ GC tetramer staining. Data are presented as the percentage of CD1D-aGC tetramer-positive cells among $\mathrm{CD}^{+}$cells. All tissues from the same animal are identified by color. c Co-receptor usage, d CD161 expression, e CD69 expression, and $\mathbf{f}$ NKG2A expression among iNKT cells from rhesus macaque PBMC and tissues identified in Online Resource 3 expressed as a percentage of all CD1D-aGC tetramer-positive cells

macaques that mirror what is observed in humans. Together, these data reveal a remarkable shared history within a specialized subset of primate $\mathrm{T}$ cells.

Though CD1 genes are present in all examined mammalian genomes, the number of functional $\mathrm{CD} 1$ genes varies from 1 to 13 , depending on the species. If one were to include pseudogenes as well, this number would be even higher. In this context, with the exception of a single-gene duplication of CD1A in olive baboons, it is remarkable that the simian CD1 locus has remained static with exactly five syntenic CD1 genes. These data significantly extend the known evolutionary history of CD1 in a number of ways. First, our data support the existing consensus that CD1D is the last common ancestor for all $\mathrm{CD} 1$ genes in primates. CD1E was likely the second paralog to emerge by gene duplication, and upon neofunctionalization, provided a non-redundant function (antigen processing) compared to its parent CD1D (antigen presentation) (de la Salle et al. 2005). Finally, CD1B, CD1C, and CD1A duplicated most recently, and in the case of CD1A, 
have repeatedly experienced strong selection to diversify its antigen-binding domain (data not shown). The current paradigm of mammalian CD1 is quite anthropomorphic, with annotations based on homology to the five human genes. Thus, it is not known if there are more than these five genes in nonsimian mammals or a different set of genes in other animals.

The evolution of MHC among primates as a whole appears to have followed a very different path, especially among New World monkeys (Adams and Parham 2001). Perhaps a closer analogy to the situation for CD1 described here are the nonpolymorphic antigen-presenting genes within the MHC locus, such as HLA-E. HLA-E binds peptides derived from HLA-A leader sequences and acts as an inhibitory ligand for the CD94:NKG2A receptor of NK cells (Braud et al. 1998). Homologs of human HLA-E have been described in apes, Old World, and New World monkeys (Boyson et al. 1995; Knapp et al. 1998). Specifically, the peptide-binding groove is highly conserved with only three amino acid differences across all primate HLA-E sequences (O'Callaghan et al. 1998). This is quite similar to what we report for the CD1 sequences. For HLA-E, maintaining a conserved mode of interaction between NK cells and other somatic cells provides a consistent way to achieve tumor or immune surveillance. Like CD1, HLA-E has also been shown to bind a more diverse array of antigens and stimulate $\mathrm{T}$ cells via their $\mathrm{T}$ cell receptors (Hansen et al. 2016). The benefit here may be the activation of T cells with an "innate"-like phenotype to provide early protection against infectious challenge.

We discovered several tissue-specific phenotypes of iNKT cells in rhesus macaques that have not been previously appreciated. Tissues were obtained from animals undergoing necropsy after malaria challenge or BCG vaccination, so it is possible that some of these tissue phenotypes might not be present in naïve animals. In one animal, we found iNKT cells that expressed TCR- $\gamma \delta$, specifically the $\mathrm{V} \gamma 9$ and $V \delta 1$ gene segments. Exactly this phenotype has been described among blood iNKT cells in humans (Uldrich et al. 2013). The crystal structure of CD1D- $\alpha$ GalCer-TCR- $\gamma \delta$ revealed that V $\delta 1$ dominated interactions with the iNKT TCR. Other studies have confirmed a role for $\mathrm{V} \delta 1$ in mediating recognition of CD1C and CD1D presented lipid antigens in humans (Bai et al. 2012; Ly et al. 2013; Porcelli et al. 1992). Our results suggest that the V $\delta 1$ paradigm may also extend to rhesus macaques. We also discovered high levels of CD161 on iNKT cells in tissues, but not blood, of rhesus macaques. CD161 is an established marker of iNKT cells in both blood and tissues of humans but has not been reported previously in studies of rhesus macaques, most of which have focused on blood (Gansuvd et al. 2003). In humans, CD161 was recently shown to act as a co-stimulatory molecule and mark T cells with an innate-like transcriptional signature (Fergusson et al. 2014). In rhesus macaques, $\mathrm{CD} 161^{+} \mathrm{CD} 8^{+} \mathrm{T}$ cells were found to be enriched at mucosal sites compared to blood and showed enhanced IFN- $\gamma$, IL-17, and perforin production (Rout, 2016). Thus, it is highly likely that the functional profiles and transcriptional signatures of iNKT cells in rhesus macaques mirror that of humans. One notable contrast that has been reported previously and confirmed by the data presented here is that iNKT cells in rhesus macaques are typically $\mathrm{CD} 4^{-} \mathrm{CD}^{+}$while those in humans are mostly $\mathrm{CD} 4^{+} \mathrm{CD} 8^{-}$or $\mathrm{CD} 4^{-} \mathrm{CD} 8^{-}$(Fig. $4 \mathrm{c}$ ) (Gansuvd et al. 2003). The role of the co-receptor in facilitating antigen recognition and function of iNKT cells has not been thoroughly investigated. One study showed that anti-CD4 specifically inhibited proliferation and cytokine secretion but not cytotoxicity by $\mathrm{CD}^{+}$human iNKT cells (Chen et al. 2007). In mice, iNKT cells are positively selected by homotypic interactions of $\mathrm{CD} 4^{+} \mathrm{CD} 8^{+}$thymocytes and then emerge expressing only the CD4 coreceptor (Matsuda and Gapin 2005). The developmental program of iNKT cells in thymus from rhesus macaques can now also be probed using the approach described here.

We discovered that the iNKT TCR- $\beta$ chain was composed of TRBV25-1, also known as V $\beta 11$. These results apparently contradict published data suggesting iNKT cells in rhesus macaques do not express V $\beta 11$ (Gansuvd et al. 2003; Motsinger et al. 2003). Those studies used a monoclonal antibody targeting human $V \beta 11$, so it is possible that the binding epitope is absent in rhesus macaques. Indeed, we have observed that anti-human V $\beta 11$ fails to stain PBMC from rhesus macaques, supporting this hypothesis (data not shown). By contrast, we defined the TCR using template-switched PCR and show that it is sufficient to bind human CD1D tetramer after lentiviral transduction of Jurkat cells. We found the CDR3 $\beta$ sequence to consist of 12 amino acids compared to 18 in the canonical human iNKT TCR (Borg et al. 2007). Despite this marked reduction, TCR transduction studies confirmed the ability of human CD1D- $\alpha$-GalCer tetramer to bind rhesusderived iNKT TCR. A study of 54 human iNKT TCRs revealed variability of the $C D R 3 \beta$ sequence motif ranging from 11 to 18 amino acids, which is consistent with our finding (Chamoto et al. 2016).

Finally, we confined our molecular and functional analysis to CD1D and iNKT cells, but this approach could readily be applied to other CD1 genes. A recent study showed that rhesus CD1B molecules were able to bind and present a mycobacterial glycolipid to human CD1B-restricted T cells (Morita et al. 2008). However, GMM was presented by $\mathrm{CD} 1 \mathrm{C}$ to $\mathrm{CD} 8^{+} \mathrm{T}$ cells in rhesus macaques compared to $\mathrm{CD} 1 \mathrm{~B}$ and $\mathrm{CD} 4^{+} \mathrm{T}$ cells in humans (Kasmar et al. 2011; Morita et al. 2013). These data suggest that the cross-species conservation in CD1D and iNKT cell TCR interactions that we note here could extend to other CD1-restricted T cells, such as CD1B-restricted germline-encoded mycolyl-reactive (GEM) T cells (Van Rhijn et al. 2013). 
Acknowledgements The authors would like to thank Erik Layton for providing technical assistance, Stephen De Rosa for assisting with the development of the intracellular cytokine staining (ICS) panel, D. Branch Moody for providing K562-CD1D transfected cells, and Stanley Riddell for providing the packaging vector.

Funding information This work was supported by the University of Washington Department of Medicine, the Bill \& Melinda Gates Foundation (OPP1190451 to C.S.), the National Institutes of Health (R01-HD076862 to W.J.S. and K99-HD090201 to D.B.W.), and the Foundation for the National Institutes of Health through the Collaboration for AIDS Vaccine Development of the Bill \& Melinda Gates Foundation (OPP1147555).

Open Access This article is distributed under the terms of the Creative Commons Attribution 4.0 International License (http:// creativecommons.org/licenses/by/4.0/), which permits unrestricted use, distribution, and reproduction in any medium, provided you give appropriate credit to the original author(s) and the source, provide a link to the Creative Commons license, and indicate if changes were made.

\section{References}

Adams EJ, Parham P (2001) Species-specific evolution of MHC class I genes in the higher primates. Immunol Rev 183:41-64. https://doi. org/10.1111/j.1365-3032.1968.tb01033.x

Bai L, Picard D, Anderson B, Chaudhary V, Luoma A, Jabri B, Adams EJ, Savage PB, Bendelac A (2012) The majority of CD1d-sulfatidespecific T cells in human blood use a semiinvariant V $\delta 1$ TCR. Eur J Immunol 42:2505-2510. https://doi.org/10.1002/eji.201242531

Balk SP, Bleicher PA, Terhorst C (1991) Isolation and expression of cDNA encoding the murine homologues of CD1. J Immunol 146: 768-774

Borg NA, Wun KS, Kjer-nielsen L, Wilce MCJ, Pellicci DG, Koh R, Besra GS, Bharadwaj M, Godfrey DI, Mccluskey J, Rossjohn J (2007) CD1d-lipid-antigen recognition by the semi-invariant NKT T-cell receptor. Nature 448:3-8. https://doi.org/10.1038/ nature 05907

Boyson JE, McAdam SN, Gallimore A, Golos TG, Liu X, Gotch FM, Hughes AL, Watkins DI (1995) The MHC E locus in macaques is polymorphic and is conserved between macaques and humans. Immunogenetics 41:59-68. https://doi.org/10.1007/BF00182314

Braud VM, Allan DSJ, O'Callaghan CA, Söderström K, D'Andrea A, Ogg GS, Lazetic S, Young NT, Bell JI, Phillips JH, Lanier LL, McMichael AJ (1998) HLA-E binds to natural killer cell receptors CD94/NKG2A, B and C. Nature 391:795-799

Carrington M, Nelson GW, Martin MP, Kissner T, Vlahov D, Goedert JJ, Kaslow R, Buchbinder S, Hoots K, O’Brien SJ (1999) HLA and HIV-1: heterozygote advantage and $\mathrm{B} * 35-\mathrm{CW} * 04$ disadvantage. Science (80-.) 283:1748-1752

Chamoto K, Guo T, Imataki O, Tanaka M, Nakatsugawa M, Ochi T, Yamashita Y, Saito AM, Saito TI, Butler MO, Hirano N (2016) CDR3 $\beta$ sequence motifs regulate autoreactivity of human invariant NKT cell receptors. J Autoimmun 68:39-51. https://doi.org/10. 1016/j.jaut.2015.12.005

Chen X, Wang X, Besra GS, Gumperz JE (2007) Modulation of CD1drestricted NKT cell responses by CD4. J Leukoc Biol 82:14551465. https://doi.org/10.1189/jlb.0307163

Chen CY, Huang D, Wang RC, Shen L, Zeng G, Yao S, Shen Y, Halliday L, Fortman J, McAllister M, Estep J, Hunt R, Vasconcelos D, Du G, Porcelli SA, Larsen MH, Jacobs WR, Haynes BF, Letvin NL, Chen ZW (2009) A critical role for CD8 T cells in a nonhuman primate model of tuberculosis. PLoS Pathog 5:e1000392. https://doi.org/10. 1371/journal.ppat.1000392

de la Salle H, Mariotti S, Angenieux C, Gilleron M, Garcia-Alles L-F, Malm D, Berg T, Paoletti S, Maître B, Mourey L, Salamero J, Cazenave JP, Hanau D, Mori L, Puzo G, De Libero G (2005) Assistance of microbial glycolipid antigen processing by CD1e. Science (80-.) 310:1321-1324

Dellabona P, Padovan E, Casorati G, Brockhaus M, Lanzavecchia A (1994) An invariant V alpha 24-J alpha Q/V beta $11 \mathrm{~T}$ cell receptor is expressed in all individuals by clonally expanded CD4-8- T cells. J Exp Med 180:1171-1176

Epstein JE, Tewari K, Lyke KE, Sim BKL, Billingsley PF, Laurens MB, Gunasekera A, Chakravarty S, James ER, Sedegah M, Richman A, Velmurugan S, Reyes S, Li M, Tucker K, Ahumada A, Ruben AJ, Li T, Stafford R, Eappen AG, Tamminga C, Bennett JW, Ockenhouse CF, Murphy JR, Komisar J, Thomas N, Loyevsky M, Birkett A, Plowe CV, Loucq C, Edelman R, Richie TL, Seder RA, Hoffman SL (2011) Live attenuated malaria vaccine designed to protect through hepatic $\mathrm{CD}^{+} \mathrm{T}$ cell immunity. Science (80-.) 334:475-480

Exley M, Porcelli S, Furman M, Garcia J, Balk S (1998) CD161 (NKRP1A) costimulation of CD1d-dependent activation of human T cells expressing invariant $\mathrm{V} \alpha 24 \mathrm{~J} \alpha \mathrm{Q}$ T cell receptor $\alpha$ chains. J Exp Med 188:867-876

Fergusson JR, Smith KE, Fleming VM, Rajoriya N, Newell EW, Simmons R, Marchi E, Björkander S, Kang YH, Swadling L, Kurioka A, Sahgal N, Lockstone H, Baban D, Freeman GJ, Sverremark-Ekström E, Davis MM, Davenport MP, Venturi V, Ussher JE, Willberg CB, Klenerman P (2014) CD161 defines a transcriptional and functional phenotype across distinct human $\mathrm{T}$ cell lineages. Cell Rep 9:1075-1088. https://doi.org/10.1016/j. celrep.2014.09.045

Fernandez CS, Chan AC, Kyparissoudis K, De Rose R, Godfrey DI, Kent SJ (2009) Peripheral NKT cells in simian immunodeficiency virusinfected macaques. J Virol 83:1617-1624

Fernandez CS, Cameron G, Godfrey DI, Kent SJ (2012) Ex-vivo $\alpha$ galactosylceramide activation of NKT cells in humans and macaques. J Immunol Methods 382:150-159. https://doi.org/10.1016/ j.jim.2012.05.019

Finak G, Frelinger J, Jiang W, Newell EW, Ramey J, Davis MM, Kalams SA, De Rosa SC, Gottardo R (2014) OpenCyto: an open source infrastructure for scalable, robust, reproducible, and automated, end-to-end flow cytometry data analysis. PLoS Comput Biol 10: e1003806. https://doi.org/10.1371/journal.pcbi.1003806

Gansuvd B, Hubbard WJ, Hutchings A, Thomas FT, Goodwin J, Wilson SB, Exley MA, Thomas JM (2003) Phenotypic and functional characterization of long-term cultured rhesus macaque spleen-derived NKT cells. J Immunol 171:2904-2911

Gansuvd B, Goodwin J, Asiedu CK, Jiang XL, Jargal U, Andrades P, Exley MA, Thomas JM (2008) Invariant natural killer T cells from rhesus macaque spleen and peripheral blood are phenotypically and functionally distinct populations. J Med Primatol 37:1-11. https:// doi.org/10.1111/j.1600-0684.2007.00222.x

Garcia KC, Degano M, Stanfield RL, Brunmark A, Jackson MR, Peterson PA, Teyton L, Wilson IA (1996) An $\alpha \beta$ T cell receptor structure at $2.5 \AA$ and its orientation in the TCR-MHC complex. Science (80-.) 274:209-219

Hansen SG, Wu HL, Burwitz BJ, Hughes CM, Hammond KB, Ventura AB, Reed JS, Gilbride RM, Ainslie E, Morrow DW, Ford JC, Selseth AN, Pathak R, Malouli D, Legasse AW, Axthelm MK, Nelson JA, Gillespie GM, Walters LC, Brackenridge S, Sharpe HR, López CA, Früh K, Korber BT, McMichael AJ, Gnanakaran S, Sacha JB, Picker LJ (2016) Broadly targeted CD8+ T cell responses restricted by major histocompatibility complex E. Science (80-.) 351:714-720

Ishihara S, Nieda M, Kitayama J, Osada T, Yabe T, Kikuchi A, Koezuka Y, Porcelli SA, Tadokoro K, Nagawa H, Juji T (2000) $\alpha$ - 
Glycosylceramides enhance the antitumor cytotoxicity of hepatic lymphocytes obtained from cancer patients by activating CD3 -CD56+ NK cells in vitro. J Immunol 165:1659-1664

Jing L, Laing KJ, Dong L, Russell RM, Barlow RS, Haas JG, Ramchandani MS, Johnston C, Buus S, Redwood AJ, White KD, Mallal SA, Phillips EJ, Posavad CM, Wald A, Koelle DM (2016) Extensive CD4 and CD8 T cell cross-reactivity between alphaherpesviruses. J Immunol 196:2205-2218

Karadimitris A, Gadola S, Altamirano M, Brown D, Woolfson A, Klenerman P, Chen J-L, Koezuka Y, Roberts IAG, Price DA, Dusheiko G, Milstein C, Fersht A, Luzzatto L, Cerundolo V (2001) Human CD1d-glycolipid tetramers generated by in vitro oxidative refolding chromatography. Proc Natl Acad Sci 98:3294 3298. https://doi.org/10.1073/pnas.051604498

Kashiwase K, Kikuchi A, Ando Y, Nicol A, Porcelli SA, Tokunaga K, Nicol A (2003) The CD1d natural killer T-cell antigen presentation pathway is highly conserved between humans and rhesus macaques. Immunogenetics 54:776-781. https://doi.org/10.1007/s00251-0020527-8

Kasmar A, Van Rhijn I, Moody DB (2009) The evolved functions of CD1 during infection. Curr Opin Immunol 21:397-403. https://doi.org/ 10.1016/j.coi.2009.05.022

Kasmar AG, van Rhijn I, Cheng T-Y, Turner M, Seshadri C, Schiefner A, Kalathur RC, Annand JW, de Jong A, Shires J, Leon L, Brenner M, Wilson IA, Altman JD, Moody DB (2011) CD1b tetramers bind $\alpha \beta$ $\mathrm{T}$ cell receptors to identify a mycobacterial glycolipid-reactive $\mathrm{T}$ cell repertoire in humans. J Exp Med 208:1741-1747. https://doi.org/10. 1084/jem.20110665

Kawashima T, Norose Y, Watanabe Y, Enomoto Y, Narazaki H, Watari E, Tanaka S, Takahashi H, Yano I, Brenner MB, Sugita M (2003) Cutting edge: major CD8 T cell response to live bacillus CalmetteGuerin is mediated by CD1 molecules. J Immunol 170:5345-5348. https://doi.org/10.4049/jimmunol.170.11.5345

Kjer-Nielsen L, Borg NA, Pellicci DG, Beddoe T, Kostenko L, Clements CS, Williamson NA, Smyth MJ, Besra GS, Reid HH, Bharadwaj M, Godfrey DI, Rossjohn J, McCluskey J (2006) A structural basis for selection and cross-species reactivity of the semi-invariant NKT cell receptor in CD1d/glycolipid recognition. J Exp Med 203:661-673

Knapp L a, Cadavid LF, Watkins DI (1998) The MHC-E locus is the most well conserved of all known primate class I histocompatibility genes. J Immunol 160:189-196. https://doi.org/10.1016/j.biortech. 2004.12.005

Linnemann C, Heemskerk B, Kvistborg P, Kluin RJC, Bolotin DA, Chen X, Bresser K, Nieuwland M, Schotte R, Michels S, Gomez-Eerland R, Jahn L, Hombrink P, Legrand N, Shu CJ, Mamedov IZ, Velds A, Blank CU, Haanen JBAG, Turchaninova MA, Kerkhoven RM, Spits H, Hadrup SR, Heemskerk MHM, Blankenstein T, Chudakov DM, Bendle GM, Schumacher TNM (2013) Highthroughput identification of antigen-specific TCRs by TCR gene capture. Nat Med 19:1534-1541

Liu Y, Goff RD, Zhou D, Mattner J, Sullivan BA, Khurana A, Cantu C, Ravkov EV, Ibegbu CC, Altman JD, Teyton L, Bendelac A, Savage PB (2006) A modified $\alpha$-galactosyl ceramide for staining and stimulating natural killer T cells. J Immunol Methods 312:34-39. https:// doi.org/10.1016/j.jim.2006.02.009

Ly D, Kasmar AG, Cheng T-Y, de Jong A, Huang S, Roy S, Bhatt A, van Summeren RP, Altman JD, Jacobs WR, Adams EJ, Minnaard AJ, Porcelli SA, Moody DB (2013) CD1c tetramers detect ex vivo T cell responses to processed phosphomycoketide antigens. J Exp Med 210:729-741

Matsuda JL, Gapin L (2005) Developmental program of mouse V $\alpha 14$ i NKT cells. Curr Opin Immunol 17:122-130. https://doi.org/10. 1016/j.coi.2005.01.002

Morita D, Katoh K, Harada T, Nakagawa Y, Matsunaga I, Miura T, Adachi A, Igarashi T, Sugita M (2008) Trans-species activation of human $\mathrm{T}$ cells by rhesus macaque $\mathrm{CD} 1 \mathrm{~b}$ molecules. Biochem
Biophys Res Commun 377:889-893. https://doi.org/10.4324/ 9781315272405

Morita D, Hattori Y, Nakamura T, Igarashi T, Harashima H, Sugita M (2013) Major T cell response to a mycolyl glycolipid is mediated by CD1c molecules in rhesus macaques. Infect Immun 81:311-316

Motsinger A, Azimzadeh A, Stanic AK, Johnson RP, Van Kaer L, Joyce S, Unutmaz D (2003) Identification and simian immunodeficiency virus infection of CD1d-restricted macaque natural killer T cells. J Virol 77:8153-8158

Nicol A, Nieda M, Koezuka Y, Porcelli S, Suzuki K, Tadokoro K, Durrant S, Juji T (2000) Human invariant V $\alpha 24+$ natural killer T cells activated by a-galactosylceramide (KRN7000) have cytotoxic antitumour activity through mechanisms distinct from $\mathrm{T}$ cells and natural killer cells. Immunology 99:229-234. https://doi.org/10.1046/j. 1365-2567.2000.00952.x

Nieda M, Nicol A, Koezuka Y, Kikuchi A, Takahashi T, Nakamura H, Furukawa H, Yabe T, Ishikawa Y, Tadokoro K, Juji T (1999) Activation of human $\mathrm{V} \alpha 24 \mathrm{NKT}$ cells by $\alpha$-glycosylceramide in a CD1d- restricted and V $\alpha 24$ TCR-mediated manner. Hum Immunol 60:10-19. https://doi.org/10.1016/S0198-8859(98)00100-1

O'Callaghan CA, Tormo J, Willcox BE, Braud VM, Jakobsen BK, Stuart DI, McMichael AJ, Bell JI, Jones EY (1998) Structural features impose tight peptide binding specificity in the nonclassical MHC molecule HLA-E. Mol Cell 1:531-541. https://doi.org/10.1016/ S1097-2765(00)80053-2

Porcelli S, Yockey CE, Brenner MB, Balk SP (1993) Analysis of T cell antigen receptor (TCR) expression by human peripheral blood CD48- alpha/beta T cells demonstrates preferential use of several $\mathrm{V}$ beta genes and an invariant TCR alpha chain. J Exp Med 178:1-16. https://doi.org/10.1084/jem.178.1.1

Porcelli S, Morita CT, Brenner MB (1992) CDlb restricts the response of human CD4-8-T lymphocytes to a microbial antigen. Nature 360: 593-597

Reinink P, Van Rhijn I (2016) Mammalian CD1 and MR1 genes. Immunogenetics 68:515-523. https://doi.org/10.1007/s00251-0160926-x

Riddell SR, Watanabe KS, Goodrich JM, Li CR, Agha ME, Greenberg PD (1992) Restoration of viral immunity in immunodeficient humans by the adoptive transfer of T cell clones. Science 257: 238-241. https://doi.org/10.1126/science.1352912

Rout N (2016) Enhanced Th1/Th17 functions of CD161+ CD8+ T cells in mucosal tissues of rhesus macaques. PLoS One 11:e0157407. https://doi.org/10.1371/journal.pone.0157407

Rout N, Else JG, Yue S, Connole M, Exley MA, Kaur A (2010a) Heterogeneity in phenotype and function of CD8+ and CD4/CD8 double-negative natural killer T cell subsets in sooty mangabeys. J Med Primatol 39:224-234. https://doi.org/10.1111/j.1600-0684. 2010.00431.x

Rout N, Else JG, Yue S, Connole M, Exley MA, Kaur A (2010b) Paucity of CD4+ natural killer T (NKT) lymphocytes in sooty mangabeys is associated with lack of NKT cell depletion after SIV infection. PLoS One 5:e9787. https://doi.org/10.1371/journal.pone.0009787

Rout N, Greene J, Yue S, O'Connor D, Johnson RP, Else JG, Exley MA, Kaur A (2012) Loss of effector and anti-inflammatory natural killer $\mathrm{T}$ lymphocyte function in pathogenic simian immunodeficiency virus infection. PLoS Pathog 8:e1002928. https://doi.org/10.1371/ journal.ppat. 1002928

Salomonsen J, Sørensen MR, Marston DA, Rogers SL, Collen T, van Hateren A, Smith AL, Beal RK, Skjødt K, Kaufman J (2005) Two $\mathrm{CD} 1$ genes map to the chicken MHC, indicating that CD1 genes are ancient and likely to have been present in the primordial MHC. Proc Natl Acad Sci U S A 102:8668-8673

Uldrich AP, Le Nours J, Pellicci DG, Gherardin NA, McPherson KG, Lim RT, Patel O, Beddoe T, Gras S, Rossjohn J, Godfrey DI (2013) CD1d-lipid antigen recognition by the $\gamma \delta$ TCR. Nat Immunol 14: $1137-1145$ 
Van Rhijn I, Kasmar A, de Jong A, Gras S, Bhati M, Doorenspleet ME, de Vries N, Godfrey DI, Altman JD, de Jager W, Rossjohn J, Moody DB (2013) A conserved human T cell population targets mycobacterial antigens presented by CD1b. Nat Immunol 14: 706-713

Wills C, Green DR (1995) A genetic herd-immunity model for the maintenance of MHC polymorphism. Immunol Rev 143:263-292. https://doi.org/10.1111/j.1600-065X.1995.tb00679.x
Zhou Q, Schneider IC, Edes I, Honegger A, Bach P, Schönfeld K, Schambach A, Wels WS, Kneissl S, Uckert W, Buchholz CJ (2012) T-cell receptor gene transfer exclusively to human CD8(+) cells enhances tumor cell killing. Blood 120:4334-4342

Publisher's note Springer Nature remains neutral with regard to jurisdictional claims in published maps and institutional affiliations. 